University of New Hampshire

University of New Hampshire Scholars' Repository

Faculty Publications

2018

\title{
An Integrated Approach to Personality Assessment Based on the Personality Systems Framework
}

John D. Mayer

University of New Hampshire, Durham, jack.mayer@unh.edu

Follow this and additional works at: https://scholars.unh.edu/faculty_pubs

\section{Comments}

This is an Accepted Manuscript of an article to be published by Taylor \& Francis in Journal of Personality Assessment in 2018, available online: https://www.tandfonline.com/loi/hjpa20

\section{Recommended Citation}

Mayer, John D., "An Integrated Approach to Personality Assessment Based on the Personality Systems Framework" (2018). Journal of Personality Assessment. 3.

https://scholars.unh.edu/faculty_pubs/3

This Article is brought to you for free and open access by University of New Hampshire Scholars' Repository. It has been accepted for inclusion in Faculty Publications by an authorized administrator of University of New Hampshire Scholars' Repository. For more information, please contact Scholarly.Communication@unh.edu. 
RUNNING HEAD: AN INTEGRATED APPROACH

An Integrated Approach to Personality Assessment

Based on the Personality Systems Framework

John D. Mayer

University of New Hampshire

\begin{abstract}
Author Notes
The author is grateful to Benjamin T. Gliko whose questions focused my attention on the issues addressed herein and who commented on a pre-publication version of this manuscript. I am grateful as well to Victoria M. Bryan, Susan Hess, and Lorelei T. Himlin, who read and commented on earlier drafts of the manuscript. Joni L. Mihura generously commented on my treatment of scores from the Rorschach Performance Assessment System. Any flaws or inaccuracies in this work are the responsibility of the author alone.

Correspondence regarding this manuscript may be directed to John D. Mayer, Department of Psychology, 15 Academic Way, University of New Hampshire, Durham, NH 03824, email: jack.mayer@unh.edu.

Accepted for publication, 9 November, 2018, lightly revised 19 November 2018 at request of the author. Now “in press", Journal of Personality Assessment.
\end{abstract}




\begin{abstract}
Psychologists who carry out personality assessments must be conversant in diverse technical languages to describe their clients' social contexts and inner personality function. The clinician needs to understand a person's family, gender role, ethnic identity, religious beliefs, and similar qualities, and also a client's inner personality functioning, including the workings of motives, emotions. cognition, and self-control: these may be characterized by relevant psychiatric symptoms, personality traits, and individual test scores such as those on the MMPI-2$R F$ and Rorschach-Performance Assessment System. The Personality Systems Framework for Assessment ( $P S F-A$ ) can support the assessment process by organizing information about both an individual's context and personality function, freeing the professional to optimally focus on characterizing their clients.
\end{abstract}


An Integrated Approach to Personality Assessment

Based on the Personality Systems Framework

In a successful personality assessment, the clinician meets with the client and develops an "in-depth understanding of an individual" so as to explain the person's inner mental makeup and behavioral expressions (Society for Personality Assessment, 2006, pp. 355-356). The assessment is often initiated by a health professional or educator who poses a question such as: "Why is this individual behaving disruptively?", or by a mental health client who asks: "Do I have a learning disability?", or "Why am I so unmotivated?". To conduct the assessment, the clinician collects data about the person through interviews, test administration, and other means and then integrates the data to answer the referral question (Society for Personality Assessment, 2006, pp. 355-356).

Assessment professionals draw on multiple areas of expertise to carry out the assessment. They use their clinical training to form a therapeutic alliance, to create common goals with the client (Laska, Gurman, \& Wampold, 2014), and to provide feedback in a therapeutic fashion (Finn \& Martin, 2013; Finn \& Tonsager, 1997). The professionals also draw on their knowledge of interviewing and testing to gather information about a client, and on their professional experience at integrating such information to provide a holistic picture of a person while addressing the referral issue.

Integrating client information from the referral, interview, and tests can be challenging. Professionals must be cognizant of the technical languages of family dynamics, educational systems and work settings, and inclusive ways of discussing ethnicity, religion, and genderrelated identity (Lopez, 2002). At the same time, they must speak the languages of inner personality functioning, including the technical languages of psychiatric symptoms, personality traits, and contemporary mental tests that range from intelligence assessments to tests of psychopathology (Harwood, Beutler, \& Groth-Marnat, 2011).

\section{Integrative Frameworks in Assessment}

To organize assessment data, professionals often draw on frameworks variously referred to as integrative, pan-theoretical and unified, (e.g., Anchin, 2008; Beutler, 1995; Blais \& Smith, 2014; Blais \& Hopwood, 2017; Fernndez-lvarez, Consoli, \& Gmez, 2016; Magnavita, 2008). Such integrative approaches reduce the confusion that may result from switching terminology from one theoretical perspective of the field to another (Beutler, 1995, p.52) and keep the focus on the person rather than disputes in the field (Mayer, 1998a; but see Green, 2015; and Maddi, 2006, for dissenting views). The careful organization of assessment information also promotes the adequate conceptualization of the information collected, and clarifies possible limits or gaps in the data at hand (Sugarman, 1991). 
Blais and Hopwood (2017; see also Blais \& Smith, 2014) recently suggested three integrative approaches for recording information about clinical assessments. Their outlines for assessment data included (a) a hierarchy of psychiatric symptoms based on factor analyses (b) an interpersonal-situation outline based on the psychodynamic approach of Harry Stack Sullivan, and (c) a transtheoretical model of personality, that outlined key personality functions, and that drew on an integration called the Personality Systems Framework (Mayer, 2015). The present work draws on that Personality Systems Framework as well, and explores its potential to organize diverse assessment data according to the environment that surrounds personality, and according to personality's inner functions.

\section{A Brief Introduction to the Personality Systems Framework}

The personality systems framework was introduced in 1993 to integrate the study of personality across competing theoretical and research approaches of the time (Mayer, 1993; Mayer, 1998a). The framework's unifying idea was that theorists almost universally agreed that personality was a system, and that the study of a system could be divided into four pantheoretical topics: (a) personality's location and definition, (b) its key parts, (c) organization, and (d) development (Mayer, 1998a).

Colleagues responded to the framework by asking such questions as "Would preserving theory-by-theory approaches be better?" (Funder, 1998; Maddi, 2006), "Would simpler representations of personality be possible?" (Sheldon \& Kasser, 1995), and "Could the placement of personality's functional areas be clarified?” (e.g., J. A. Singer, 1998). These questions led to improved conceptualizations, clarifications, and other refinements to the approach (Mayer, 1998b; Mayer \& Lang, 2011; Mayer, 2015). Alternative integrations also are available, such as Mischel and Shoda's social-cognitive Cognitive-Affective Personality System (CAPS, 1995) and Sheldon's humanistically-oriented Multilevel Personality in Context (MPIC) (Sheldon, Cheng, \& Hilpert, 2011).

\section{Scope of this Review}

The present work describes an extension of the Personality Systems Framework to assessment, referred to here as the Personality Systems Framework for Assessment, or PSF-A, that builds on Blais and Hopwood's (2017) recent contribution. The PSF-A is composed of a contextual organization that outlines demographic and background information about the client, and a functional organization that draws together information about a person's inner personality processes and their expressions. By doing so, the framework can support clinicians' expertise in reasoning about their clients. The next sections examine that integration.

\section{Personality as a System}

Personality can be regarded as a set of interrelated parts - a system - analogous in some ways to a highway system, a school system, or the peripheral nervous system. A school system is 
made up of its students, teachers, and administrators as well as its classrooms, buildings, and athletic fields. Systems also typically interact with their neighbors: A given school system interacts with its students' families and other community members, the neighborhood in which it is situated, and the local, state and federal governments that maintain and regulate it. A given school can be best understood in its context. It is similarly helpful to understand personality in context. One challenge to studying a personality, however, is that in contrast to a school system, personality is psychological and has no physical definition analogous to a student or teacher. The Personality Systems Framework therefore employs conceptual dimensions often used in the sciences to locate personality amidst its surroundings.

\section{The Personality Systems Framework for Assessment (PSF-A) Contextual Outline}

\section{The Foundation of the Contextual Outline}

The three-dimensional view of the individual. The first contextual organization of the PSF-A defines and locates personality. More specifically, personality—and a person — are positioned amidst their surroundings in three dimensions: (a) molecular-molar, (b) inner-outer, and (c) developmental (Mayer, 1995b), according to a locational diagram. That diagram is used here to organize assessment data.

The molecular-molar (or biopsychosocial) dimension. From the client's-eye view, one's self, or "I", or awareness is typically experienced in the head (although some people are inclined to experience it in their hearts or chests). Technically, scientists typically regard psychological phenomena as emerging from the brain along a molecular-molar continuum. The general idea is that smaller systems combine to form larger systems: Atoms combine to form molecules, molecules to form cells, cells to form bodily organs, and the brain's neural processes combine to form psychological experience. Many people together form social groups.

The molecular-molar continuum spanning from the brain to social groups, is depicted as the vertical dimension of Figure 1 where it distinguishes the brain (near the bottom) from the individual's psychological processes — emergent from the brain — and then depicts social groups. (This portion of the continuum is often referred to as the biopsychosocial portion).

The inner-outer dimension. Clients also possess an inner or private personality that can be distinguished from what they express in the outer world (J. L. Singer, 1984). The second, horizontal, dimension of Figure 1 separates the psychological processes (and brain) inside the person from their outer environments.

Each individual has a unique outer environment of defined settings: a place to sleep, a neighborhood to inhabit, a workplace (Figure 1, lower right). A mechanic might work in a local garage to repair cars; students learn in a classroom; the health-conscious navigate to a gym, the 
gourmand to a new restaurant. These settings can become psychologically relevant, as when a client with substance dependence spends hours in a bar instead of at work.

Figure 1. Personality and its Neighboring Systems. Modified from Mayer and Allen (2013, Figure 1), in compliance with the regulations and copyright rules of the American Psychological Association, as indicated in Section 3 of the APA Permissions Policy, downloaded 2017, September $17^{\text {th }}$ from http://www.apa.org/about/contact/copyright/.
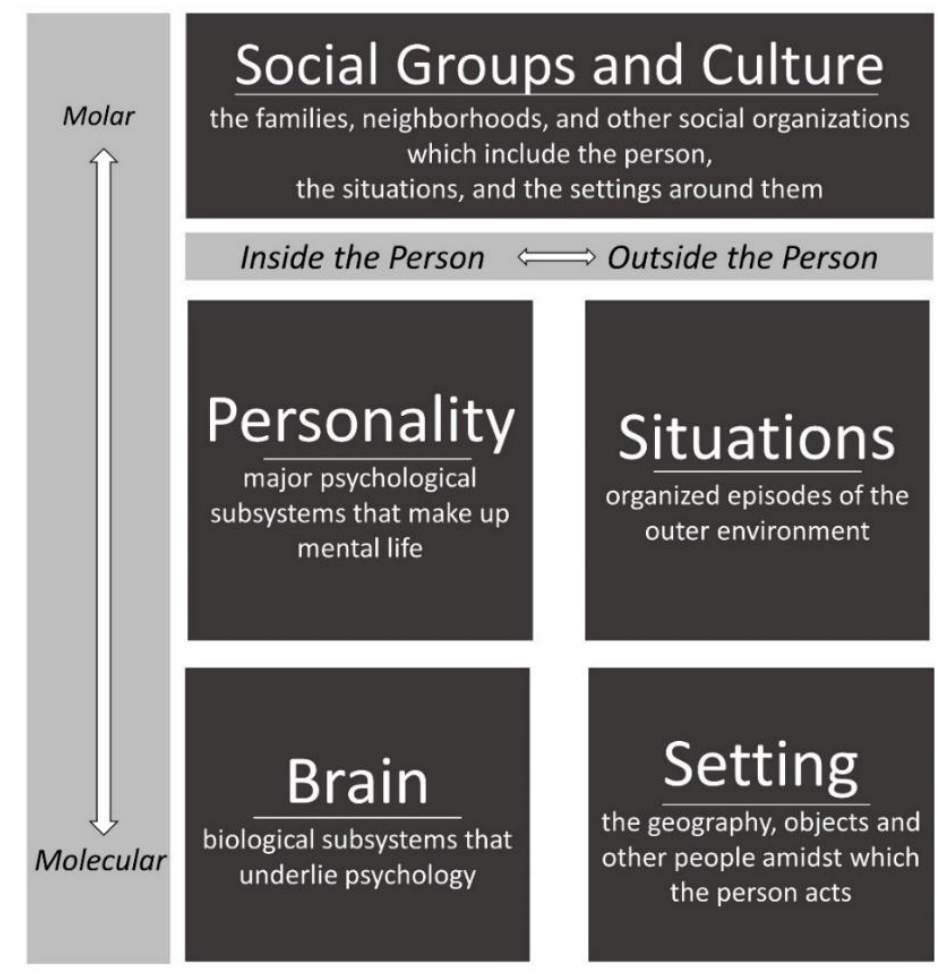
outer environment
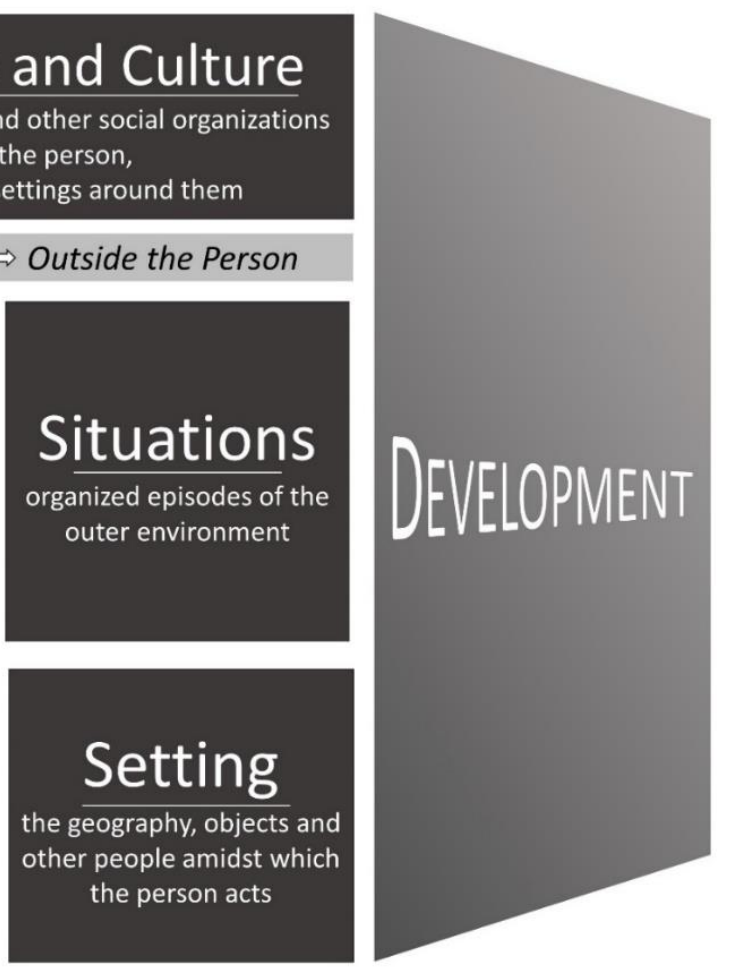

Psychological situations emerge from the aforementioned settings. Whereas one young person might regard a high school study hall as a chance to clown around, a second might find the same study hall key to preparing for an exam. How people perceive a situation determines how they act in them (e.g., Mischel \& Shoda, 1995). The first student entertains his classmates; the second studies intently (Figure 1, middle right).

Finally, each person is part of more global systems: the groups and cultures that surround them (Figure 1, top). Clients are aware — often acutely so — of the social pressures on them from groups that range from their immediate family to the communities of which they are part.

The developmental (time) dimension. The third, developmental, dimension depicts the idea that each person is in transit through time: from the nursery, to school, to a job and family, in more-or-less synchrony with sociocultural norms and expectations (Erikson, 1950; Helson, 
Mitchell, \& Moane, 1984). The third dimension of Figure 1 moves from earlier experience (front) to future time (back), adding depth.

Although some have argued that one biopsychosocial dimension may be organization enough for personality and its surroundings (Sheldon, 2011), these three dimensions add clarity and provide a more complete description of the person-in-context (Mayer \& Lang, 2011).

\section{Describing a Person's Context Using the Contextual Outline}

In a good clinical interview, assessors collect information about their clients' biopsychosocial contexts that relate to the assessment question. The PSF-A's contextual outline can help systematize how that information is collected and recorded, as indicated in Table 1. The key areas from the locational diagram appear in the left-most column in bold. Each bolded heading divides into specific categories relevant to a person's surroundings. For example, Group Memberships and Identifications divide into demographic information, cultural identifications, family, and school and work information. Development is represented by two columns to the right labeled "Earlier relevant life history" (Column 2) and "Present concerns" (Column 3). These categories could be modified for younger or older clients to read, for example, for an adolescent, "Childhood" and "Adolescence". Examples of relevant assessment information concerning school, work, socio-economic, and other areas are placed in the grid as well (e.g., American Psychiatric Association, 2013; Brabender \& Mihura, 2016; Drill, Nakash, DeFife, \& Westen, 2015; Kici \& Westhoff, 2004).

Using the Contextual Outline: A Case Example. The use of the contextual outline can be illustrated with the case of "Luis," a 26-year-old first-generation Mexican American described by Greiger (2008). Luis arrived at his campus counseling center to discuss his sexual orientation and his feeling that gayness was wrong. A clinician might record in the "School and Work Organizations" area that Luis attended the business school; in the "Cultural Identifications" area, that he was a practicing Roman Catholic who felt guided by his religious and spiritual beliefs; and, under "Family Information," that his parents held traditional values and expectations for their children.

Luis' questions of whether he should come out to his parents (and himself) could be coded under "Situations" in terms of key interactions with family and church. Greiger (2008) argued that Luis' key struggle was between his own openness to his sexual identity, on the one hand, and his family's cultural and religious beliefs, on the other, which tended to delegitimize non-traditional sexual orientations. The tables' organization arranges the pertinent information so as to provide a clinician with an organized picture of such issues. 


\section{Table 1}

Information Relevant to Contextualizing the Individual and the Individual's Clinical Issues, Organized According to the Key Areas Surrounding Personality

\begin{tabular}{|c|c|c|}
\hline \multirow[t]{2}{*}{ General Contextual Areas } & \multicolumn{2}{|c|}{ Specific Contextually-Relevant Information: Examples } \\
\hline & From early life history & Present concerns \\
\hline \multicolumn{3}{|c|}{ Group Memberships and Identifications } \\
\hline Demographic Information & Ethnic heritage & Ethnic identification(s) \\
\hline Cultural Identifications & Religious upbringing, if any & $\begin{array}{l}\text { Current religious commitments and } \\
\text { identifications }\end{array}$ \\
\hline Family Information & $\begin{array}{l}\text { Separation(s) from parents; } \\
\text { immigration status }\end{array}$ & $\begin{array}{l}\text { Current interaction(s) with family } \\
\text { members; marital status }\end{array}$ \\
\hline School or Work Organizations & Schools attended & Workplace issues \\
\hline \multicolumn{3}{|l|}{ Interactions with Situations } \\
\hline General Conduct & Childhood conduct issues & Legal issues \\
\hline Attachment & Family relationships & $\begin{array}{l}\text { Adult attachment symptoms and } \\
\text { patterns }\end{array}$ \\
\hline $\begin{array}{l}\text { Situations in which symptomatic } \\
\text { behavior emerges }\end{array}$ & History of symptoms and issues & $\begin{array}{l}\text { Present situations and conditions that } \\
\text { trigger issues }\end{array}$ \\
\hline Role models & $\begin{array}{l}\text { Childhood role models for the } \\
\text { relevant behaviors }\end{array}$ & $\begin{array}{l}\text { Role models, mentors and influential } \\
\text { individuals }\end{array}$ \\
\hline Key Events & $\begin{array}{l}\text { Key childhood events relevant to } \\
\text { the assessment }\end{array}$ & Key events relevant to the assessment \\
\hline Work Issues & Childhood school performance & $\begin{array}{l}\text { Employment status and work } \\
\text { performance }\end{array}$ \\
\hline \multicolumn{3}{|l|}{ Interactions with Settings } \\
\hline $\begin{array}{l}\text { Socioeconomic status of } \\
\text { neighborhood }\end{array}$ & $\begin{array}{l}\text { Neighborhood factors during } \\
\text { childhood }\end{array}$ & Present living situation \\
\hline Personal Care Issues & Capacity for self-care in the past & Present capacity for self-care \\
\hline Resource Issues & $\begin{array}{l}\text { Degree to which essential } \\
\text { childhood/family needs met }\end{array}$ & $\begin{array}{l}\text { Degree to which present-day needs } \\
\text { are met (e.g., food, transportation, } \\
\text { etc.) }\end{array}$ \\
\hline \multicolumn{3}{|c|}{ Biomedical and biopsychological underpinnings } \\
\hline Physical Appearance & $\begin{array}{l}\text { Childhood physical appearance } \\
\text { and stigma }\end{array}$ & Physical appearance and stigma \\
\hline Fitness and exercise & Childhood athletics participation & Current fitness/exercise levels \\
\hline Neuropsychological Conditions & $\begin{array}{l}\text { Childhood neuropsychological } \\
\text { issues }\end{array}$ & Adult neuropsychological status \\
\hline $\begin{array}{l}\text { Physical health and medical } \\
\text { concerns }\end{array}$ & $\begin{array}{l}\text { Congenital birth issues, relevant } \\
\text { early medical history }\end{array}$ & Current medical conditions \\
\hline
\end{tabular}

The bottom portion of Table 1 includes brain and other biomedical characteristics that may further refine a picture, including issues of acute or longstanding medical concerns such as 
cardiovascular issues, diabetes, or cancer, that the Diagnostic and Statistical Manual of Mental Disorders stipulates may influence the person's functioning.

Summary of Context. The first PSF-A outline organizes contextual information about a client and, by doing so, supports the clinician's broad perspective on a client's identifications, influences, and surroundings.

\section{The Personality Systems Framework for Assessment (PSF-A) \\ Outline of Personality Functions}

\section{Dividing Personality Functionality Using the Personality Systems Set}

The personality systems framework includes a contemporary division of personality into four functional areas and 13 more specific functions, referred to as the personality systems set. The four functional areas met the criteria that they were: (a) found in all personalities, (b) representative of agreed-upon key mental processes (c) as comprehensive as possible in their coverage of personality, (d) relatively distinct from one another, and (e) economical in number (Mayer, 2001, Table 1).

The first three areas are energy development, which includes motives and emotions, knowledge guidance, which includes intelligences and acquired knowledge, and action implementation, which represents the scripts, procedures, and specific skills that a person uses to execute self-expressions. Collectively, these three areas motivate, guide, plan, and execute behaviors that allow for the expression of personality. The fourth area, executive consciousness, includes consciousness, self-awareness, defense mechanisms, and coping: it "oversees the rest," and monitors and intervenes in the other areas' functions when needed (cf. Mayer, 2001, p. 456).

Figure 2 depicts the "Major functional areas" column toward the left (Mayer, 2018). To their right, each of the four functions are further divided into 13 more specific functions in the "Specific functional areas...," column. Knowledge Guidance, for example, divides into knowledge, intelligences, cognitive styles, and motivation and emotion-associated thought.

In one study of the model, nine doctoral student judges sorted 69 mental traits into the areas of the systems set: They were able to assign almost all the traits to the functional areas successfully and with higher interrater agreement than using other systems (Mayer, 2003, Study 2). Research employing multidimensional scaling has further supported the placement of the four areas along molecular-molar and inner-outer dimensions, as theorized (Barlow \& Mayer, 2014; Barlow \& Mayer, 2015). 
Figure 2. Overview of the Personality Systems Set. The diagram indicates two broad dynamics composed of four broad areas and 13 specific functional areas, as well as examples of functions within each specific area. Reproduced with permission from Mayer, 2018.

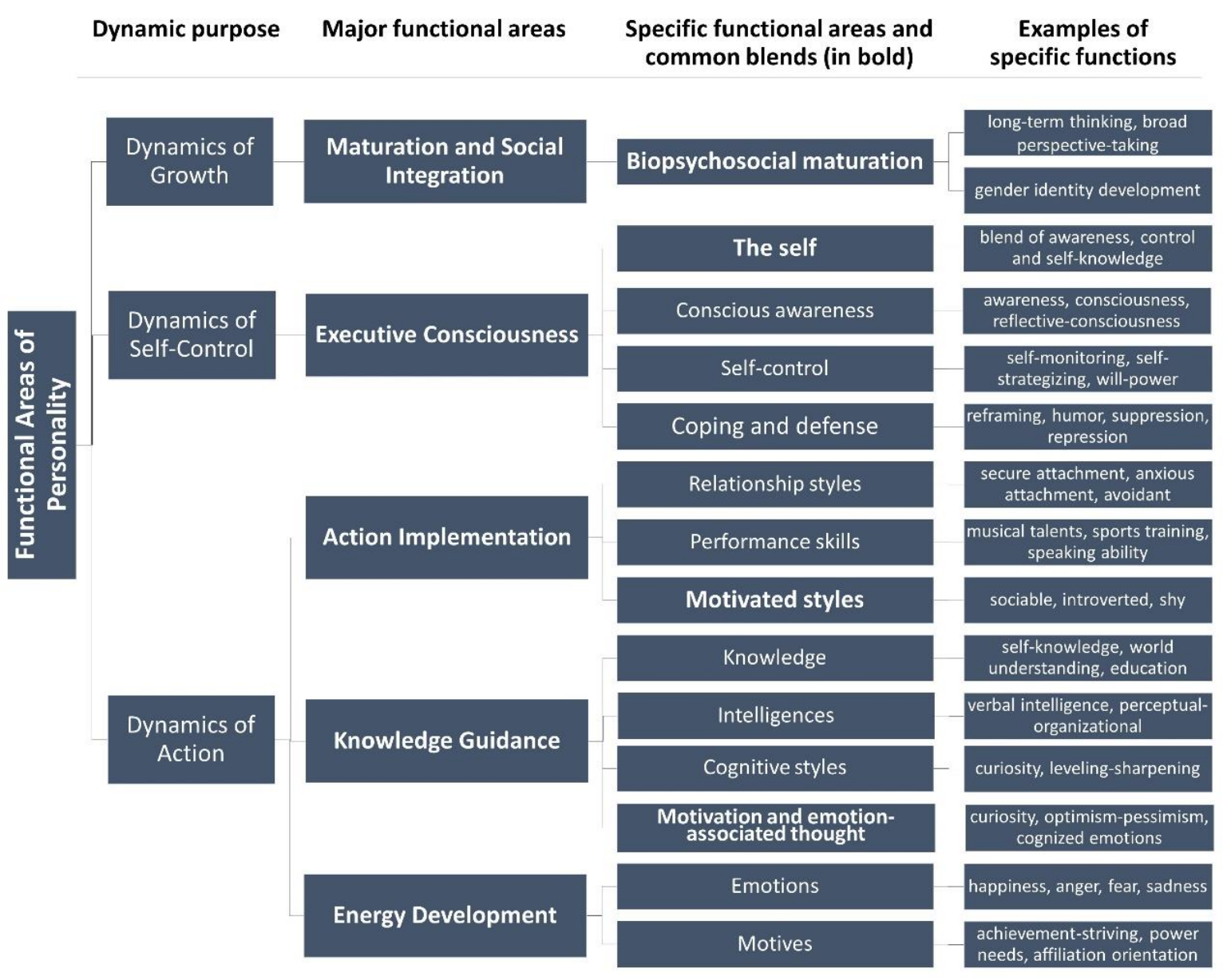

\section{The Personality Systems Set as it Relates to the Technical Languages of Assessment}

The central idea here is that the four areas and 13 specific functions of personality can organize information about a person's internal mental functioning, including the person's psychiatric symptoms, personality traits, and test scores. Before developing this idea further, however, it helps to describe briefly several representative examples of the technical lexicons that depict these symptoms, traits, and scores.

Examples of psychiatric symptom terms are drawn from the Hierarchical Taxonomy of Psychopathology (HiTOP, Kotov et al., 2017), personality traits from commonly-employed groupings described by the PSF (Mayer, 1995a), and test results by the MMPI-2-RF (Ben-Porath 
\& Tellegen, 2011) and Rorschach Performance Assessment System (R-PAS, Meyer, Viglione, Mihura, Erard, \& Erdberg, 2011). These specific examples were chosen to represent contemporary approaches to assessment, and otherwise imply no endorsement of one system or test over another. Brief descriptions of each follow.

HiTOP. The Hierarchical Taxonomy of Psychopathology (HiTOP) is a consensual language of psychiatric symptom groups introduced by 39 leaders in psychiatric diagnosis, and based on factor analyses of the co-occurrence of psychiatric symptoms across large-sample studies (Kotov et al., 2017). In the model, the $1^{\text {st }}$, Higher Order of psychopathology divides into a $2^{\text {nd }}$ Subfactor and $3^{\text {rd }}$ Spectra level of the hierarchy, that include psychopathologies that range from antagonistic-externalizing syndromes to somatoform disturbances (Kotov et al., 2017, Figure 2). Table 2 lists 11 dimensions of psychiatric syndromes from the $2^{\text {nd }}$ and $3^{\text {rd }}$ levels, to which I have added "cognitive disability" as a 12th area. The HiTOP group recognized the importance of the cognitive symptom group, but omitted it owing to a lack of relevant factor analytic studies (Kotov et al., 2017, p. 462, see also p. 466).

\section{Table 2}

Examples of the Technical Language of Psychiatric Diagnosis, Draw from the HiTOP Model of Psychiatric Symptom Clusters and Spectra

\begin{tabular}{|c|c|}
\hline $\begin{array}{l}\text { Key Classes of Symptom Clusters } \\
\text { (Spectra) }\end{array}$ & $\begin{array}{l}\text { Specific Examples of Spectra Subfactors Drawn } \\
\text { Mostly from Level } 2 \text { of the Model }{ }^{\mathrm{a}, \mathrm{b}}\end{array}$ \\
\hline Detachment & - detachment \\
\hline $\begin{array}{l}\text { Externalizing (Disinhibited and } \\
\text { Antagonistic) }\end{array}$ & $\begin{array}{l}\text { - antagonistic-externalizing } \\
\text { - antisocial behavior } \\
\text { - } \text { substance abuse }^{\mathrm{a}}\end{array}$ \\
\hline Thought Disorder & - thought disorder \\
\hline Internalizing & $\begin{array}{l}\text { - mania } \\
\text { - distress } \\
\text { - fear } \\
\text { - eating pathology } \\
\text { - sexual problems }\end{array}$ \\
\hline Somatoform $^{b}$ & - somatoform $^{\mathrm{b}}$ \\
\hline Cognitive Disabilities $^{c}$ & - cognitive disabilities ${ }^{\mathrm{c}}$ \\
\hline \multicolumn{2}{|c|}{$\begin{array}{l}\text { "I have moved substance abuse from "level 3" in Kotov's tables to the "level 2" within Disinhibited/Externalizing } \\
\text { symptoms (which also include antisocial, conduct-disordered and ADHD symptoms); in the original system it is } \\
\text { classified at the lower level. } \\
\text { b Somatoform disorders are considered a provisional member of the "spectra" level. } \\
\text { c The cognitive disabilities symptom cluster was added to chart because it is often a reason for assessment, but } \\
\text { was not covered in the HiTOP owing to an inadequate number of factor analytic studies at the time (Kotov et al., } \\
\text { 2017). }\end{array}$} \\
\hline
\end{tabular}

Conceptual groups of personality traits. To represent the language of trait psychology (Table 3), I have chosen seven groups of personality traits often discussed in the PSF. Six of the groups are conceptually defined, such as emotion-related traits (e.g., negative affect and emotional intensity). The seventh group consists of the big five and big six personality traits: 
empirically-selected groups of traits that describe socio-emotional styles and self-control (e.g., Ashton \& Lee, 2010; Goldberg, 1993).

\section{Table 3}

\begin{tabular}{|c|c|}
\hline $\begin{array}{l}\text { Commonly-Discussed Groups of Traits with Brief } \\
\text { Descriptions of Each }\end{array}$ & Specific Examples \\
\hline $\begin{array}{l}\text { Big Trait Sets. Big traits are traits identified through } \\
\text { factor analysis that each combines a set of more } \\
\text { specific, correlated traits. The traits typically are } \\
\text { drawn from commonly-used trait terms across human } \\
\text { languages Common sets are the Big Five and Big Six } \\
\text { (e.g., Ashton \& Lee, 2010; Goldberg, 1993). }\end{array}$ & $\begin{array}{l}\text { - } \text { agreeableness-disagreeableness }^{\mathrm{b}} \\
\text { - } \text { conscientiousness-carelessness }^{\mathrm{b}} \\
\text { - extraversion-introversion } \\
\text { - } \text { honesty/humility-dishonesty/arrogance }^{\mathrm{c}} \\
\text { - } \text { neuroticism-stability }^{\mathrm{b}} \\
\text { - openness-closedness }\end{array}$ \\
\hline $\begin{array}{l}\text { Consciousness-related traits. Describe awareness, } \\
\text { consciousness and alterations in consciousness, as } \\
\text { well as limits to consciousness involved with mental } \\
\text { defenses and coping. }\end{array}$ & $\begin{array}{l}\text { - absorption } \\
\text { - repression-sensitization } \\
\text { - adaptive level of defense } \\
\text { - coping skills }\end{array}$ \\
\hline $\begin{array}{l}\text { Emotion-Related Traits. Characterize an individual's } \\
\text { customary emotional states and emotional stability }\end{array}$ & $\begin{array}{l}\text { - negative emotionality } \\
\text { - anger-proneness }\end{array}$ \\
\hline $\begin{array}{l}\text { Intelligences and cognitive styles. Indicate general } \\
\text { intelligence and the broad intelligences into which it } \\
\text { divides (e.g., McGrew, 2009); also, cognitive styles: } \\
\text { preferred modes of thinking (e.g., Kozhevnikov, } \\
\text { Evans, \& Kosslyn, 2014) }\end{array}$ & $\begin{array}{l}\text { - general intelligence } \\
\text { - verbal-comprehension intelligence } \\
\text { - perceptual-organizational intelligence } \\
\text { - need for cognition } \\
\text { - internal/external locus of control } \\
\text { - optimism-pessimism } \\
\end{array}$ \\
\hline $\begin{array}{l}\text { Motivational (Dynamic) traits. Represent personal, } \\
\text { motivational needs (see Mayer, Faber, \& Xu, 2007). }\end{array}$ & $\begin{array}{l}\text { - need for achievement } \\
\text { - need for affiliation } \\
\text { - need for power }\end{array}$ \\
\hline $\begin{array}{l}\text { Relationship styles. Describe a person's relationships } \\
\text { with others and style of interpersonal interactions. }\end{array}$ & $\begin{array}{l}\text { - attachment, secure and insecure } \\
\text { - extraversion-introversion } \\
\text { - Machiavellianism }\end{array}$ \\
\hline $\begin{array}{l}\text { Self-related traits. Describe aspects of the self and } \\
\text { self-control. }\end{array}$ & $\begin{array}{l}\text { - self-esteem } \\
\text { - self-efficacy } \\
\text { - self-control } \\
\text { - masculinity-femininity }\end{array}$ \\
\hline
\end{tabular}

${ }^{a}$ The classification follows Mayer (1995a)

${ }^{\mathrm{b}}$ Member of the Big Five and Big Six trait groups.

${ }^{\mathrm{c}}$ Member of the Big Six only.

The Rorschach Performance Assessment System (R-PAS). The R-PAS combines a standardized administration of the Rorschach inkblots with a method for scoring test-takers' responses (Meyer et al., 2011). Test-takers examine the inkblots and construct meaning from them, drawing on their implicit models of themselves and the world to describe the images they perceive in the blot, termed percepts. The respondents' test behavior and percepts are then evaluated according to a carefully developed scoring procedure that yields five general groups of scores including "Administrative Behaviors and Observations," "Engagement and Cognitive 
Processing," and "Self and Other Representations;" the complete set can be found in the lefthand column of Table 4 along with brief descriptions of each area and examples of scores. For example, within the "Engagement and Cognitive Processing" group exist Human Movement (M) responses, which reflect psychological resources and positive adaptation, and Synthesis (Sy) responses, which indicate the test-taker's integration of concepts. Most of the Table 4 scores are "Page 1 Profile Summary Scores"- those with the greatest research support, although the table also includes some subsidiary scores (Meyer et al., 2011).

\section{Table 4}

Examples of Technical Language Related to Key Psychological Tests: Focus on the Rorschach Performance Assessment System (R-PAS)

\begin{tabular}{|c|c|c|}
\hline \multicolumn{2}{|c|}{$\begin{array}{l}\text { R-PAS Scale Group and Brief } \\
\text { Description }\end{array}$} & R-PAS Specific Scores ${ }^{a}$ \\
\hline $\begin{array}{l}\text { Administration } \\
\text { Behaviors and } \\
\text { Observ. (Table } \\
\text { 10.9) }\end{array}$ & $\begin{array}{l}\text { Client's trust and } \\
\text { cooperation; also, } \\
\text { threshold level of } \\
\text { cognitive competence. }\end{array}$ & $\begin{array}{l}\text { - Number of responses, R: ability and motivation on the } \\
\text { test } \\
\text { - Prompts, Pr: Reminders needed to elicit responses. Can } \\
\text { reflect limited cognitive capacities, depression, lack of trust }\end{array}$ \\
\hline $\begin{array}{l}\text { Engagement and } \\
\text { Cognitive } \\
\text { Processing } \\
\text { Domain (Table } \\
10.10)^{b}\end{array}$ & $\begin{array}{l}\text { Client's engagement in } \\
\text { the test-taking; also, } \\
\text { overall cognitive } \\
\text { sophistication and } \\
\text { mental resources }\end{array}$ & $\begin{array}{l}\text { - Complexityc: a measure of cognitive complexity calculated } \\
\text { as a function of the number of determinants, contents, locations } \\
\text { and other intricacies; can be used to adjust certain other scores. } \\
\text { - Human movement and weighted color, MC: A measure } \\
\text { of psychological resources and positive adaptation } \\
\text { - Synthesis, Sy: Meaningfully relating concepts } \\
\text { - Human movement, M: Interpersonal reasoning; good coping } \\
\text { - MC-PPD: MC in relation to Potentially Problematic } \\
\text { Determinants: A measure of coping effectiveness }\end{array}$ \\
\hline $\begin{array}{l}\text { Perception and } \\
\text { Thinking } \\
\text { Domain (Table } \\
\text { 10.11) }\end{array}$ & $\begin{array}{l}\text { Problems in cognition, } \\
\text { deficits in good } \\
\text { judgment and inaccurate } \\
\text { perception }\end{array}$ & $\begin{array}{l}\text { - Ego Impairment Index-3, EII-3: A broad index of } \\
\text { disturbed thinking reflective of psychopathology } \\
\text { - Weighted Sum of Six Cognitive Codes, WSumCog: A } \\
\text { measure of thought disorganization and disturbance } \\
\text { - Form Quality Percentages (FQo\%, FQ-\%): Reflect } \\
\text { conventionality of perception and reality testing: "u" e } \\
\text { unconventional; "o" ordinary (conventional); "-" minus } \\
\text { (distorted) } \\
\text { - Popular (P) Popular responses: Indexes sensitivity to } \\
\text { environment and conventional thinking }\end{array}$ \\
\hline $\begin{array}{l}\text { Stress and } \\
\text { Distress Domain } \\
(\text { Table 10.12) }\end{array}$ & $\begin{array}{l}\text { Emotional difficulties } \\
\text { and their influence on } \\
\text { cognition }\end{array}$ & $\begin{array}{l}\text { - Morbid content thematic code, MOR: Gloomy thinking. } \\
\text { - Sum of Shading and Achromatic Color, YTVC' } \\
\text { Sensitivity to nuances in the environment, including (for } \\
\text { less healthy individuals) implicit distress including anxiety, } \\
\text { loneliness, irritation, and/or sadness. } \\
\text { - Achromatic Color, C'd: Dampened emotional reactivity; } \\
\text { also, openness to a range of emotional experiences } \\
\text { - Color Dominance Proportion (CF+C)/SumC: Direct } \\
\text { and (in healthy individuals), often pleasant enjoyment } \\
\text { - Weighted Sum of Color (WSumC) } \text { : A general measure } \\
\text { of vitality, liveliness, and reactivity, including general } \\
\text { sensitivity to the external environment } \\
\text { - Diffuse Shading (Y): May indicate moderate to severe } \\
\text { stress }\end{array}$ \\
\hline
\end{tabular}




\begin{tabular}{l|l|l}
\hline $\begin{array}{l}\text { Self and Other } \\
\text { Representation } \\
\text { (Table 10.13) }\end{array}$ & $\begin{array}{l}\text { Indices of schema for } \\
\text { representing oneself and } \\
\text { others }\end{array}$ & $\begin{array}{l}\bullet \text { H, Ability to conceive of whole humans: better } \\
\text { understanding of self and other. } \\
\text { - M minus, M-: Human movement with poor form. } \\
\text { Atypical, distorted ways of interpreting people's actions } \\
\text { and/or intentions. } \\
\text { - Cooperative movement, COP: Positive view of interactions }\end{array}$ \\
\hline
\end{tabular}

a "Page 1 Summary Scores", are those Rorschach scores with greater research support for their interpretations. ${ }^{\mathrm{b}}$ The tables are from Meyer et al. (2011, pp. 347-366).

c Complexity has no letter code itself but appears as "CAdj" when used to indicate an adjusted score.

${ }^{\mathrm{d}}$ An added determinant score; not a summary score (Meyer, et al., 2011, Table 10.6, p. 341).

ePage 2 summary score.

\section{The Minnesota Multiphasic Personality Inventory-2-Reformulated (MMPI-2-RF).} The MMPI-2-RF is a 338-item self-report measure for which people report the presence or absence of psychiatric symptoms, as they evaluate them (Ben-Porath, 2017; McCord, 2018). Table 5 indicates some of its key scales, which fall into three groups: the validity scales, higherorder and clinical scales, and the PSY-5 (e.g., Ben-Porath \& Tellegen, 2012; McCord, 2018).

The Protocol Validity Scales indicate the degree to which the respondent adequately paid attention and responded in a reasonable fashion to the test's items. The Higher Order Scales divide into three areas of dysfunction: emotionality and internalizing (EID), thought dysfunction (THD), and behavioral/externalizing dysfunction (BXD). The more specific Restructured Clinical Scales divide into such examples as (a) somatic/cognitive scales including Gastrointestinal Complaints (GIC), (b) internalizing scales such as Helplessness/Hopelessness (HLP), and (c) interpersonal and interest scales such as Interpersonal Passivity (IPP). Each area is briefly described in the table (column 2).

The last MMPI-2-RF category, the PSY-5, represents five factor-based scales of the test that include such global characteristics as a respondent's level of Aggressiveness (AGGR-r) and of Psychoticism (PSYC-r) (the "r" designates that the scales are revised). See Table 5 for a more complete list of scores.

\section{Application of the Personality Systems Set to Describing a Person's Inner Mental Function}

The integration of assessment terms. The technical languages of mental assessments, although diverse, share in common that their terms characterize one or more areas of personality function (Averill, 1992; Mayer, 1995a; Mayer, 2015). The diverse lexicons, therefore, can be organized by the four broad areas and 13 specific functions of the personality systems set, which are copied into the left-most column of Table 6 .

The (a) Executive Consciousness area appears first (top left), and under it the more specific areas it encompasses, including self-control and coping and defense mechanisms. These are followed by (b) Action Implementation including relationship styles and performance skills, (c) Knowledge Guidance, including acquired knowledge, schemas, and intelligences, and (d) Energy Development with its emotions and motives. A $14^{\text {th }}$ broad category labeled Mixed 
Biopsychological Functions is helpful to complete the consideration of an individual's status: This category includes terms that characterize mental processes closely tied to brain function, as in the cases of certain neuropsychological, addictive, and mood disorders.

\section{Table 5}

Examples of Technical Language Related to Key Psychological Tests: Focus on the Minnesota Multiphasic Personadlity Inventory 2-Restructured Form ${ }^{\mathrm{a}}$

\begin{tabular}{|c|c|c|}
\hline \multicolumn{2}{|c|}{$\begin{array}{l}\text { MMPI-2-RF Scale Group and Brief } \\
\text { Description }\end{array}$} & \multirow{2}{*}{$\begin{array}{l}\text { MMPI-2-Rf specific scores } \\
\text { - Uncommon Virtues, L-r } \\
\text { - Infrequent Somatic Responses, Fs } \\
\text { - Infrequent Psychopathology Responses, Fp-r }\end{array}$} \\
\hline $\begin{array}{l}\text { I. Protocol } \\
\text { Validity Scales }\end{array}$ & $\begin{array}{l}\text { Scales reflecting trustworthiness of } \\
\text { responses to the test }\end{array}$ & \\
\hline \multirow[t]{5}{*}{$\begin{array}{l}\text { II. Higher- } \\
\text { Order and } \\
\text { Restructured } \\
\text { Clinical Scales }\end{array}$} & $\begin{array}{l}\text { Somatic/cognitive scales } \\
\text { Physical concerns and problems } \\
\text { with concentration and } \\
\text { cognition. }\end{array}$ & $\begin{array}{l}\text { - Gastrointestinal Complaints, GIC } \\
\text { - Head Pain Complaints, HPC } \\
\text { - Neurological Complaints, NUC } \\
\text { - Cognitive Complaints, COG } \\
\end{array}$ \\
\hline & $\begin{array}{l}\text { Internalizing/emotional scales } \\
\text { Inner experiences of negative } \\
\text { emotion and distress }\end{array}$ & \begin{tabular}{|l|} 
- Suicidal/Death Ideation, SUI \\
• Helplessness/Hopelessness, HLP \\
• Behavior-Restricting Fears, BRF
\end{tabular} \\
\hline & $\begin{array}{l}\text { Thought dysfunction scales } \\
\text { Aberrant cognitions }\end{array}$ & $\begin{array}{l}\text { - Ideas of Persecution, RC6 }{ }^{\mathbf{b}} \\
\text { - Aberrant Experiences, RC8 }\end{array}$ \\
\hline & $\begin{array}{l}\text { Behavioral/externalizing scales } \\
\text { Tendencies to act out and blame } \\
\text { others, criminality and substance } \\
\text { abuse }\end{array}$ & $\begin{array}{l}\text { - Juvenile Conduct Problems, JCP } \\
\text { - Substance Abuse, SUB } \\
\text { - Aggression, AGG }\end{array}$ \\
\hline & $\begin{array}{l}\text { Interpersonal and interest scales } \\
\text { Limits in interpersonal } \\
\text { relationships and personal } \\
\text { interests }\end{array}$ & $\begin{array}{l}\text { • Interpersonal Passivity, IPP } \\
\text { • Social Avoidance, SAV } \\
\text { - Aesthetic-Literary Interests, AES }\end{array}$ \\
\hline $\begin{array}{l}\text { III. PSY-5 } \\
\text { Scales }^{b}\end{array}$ & $\begin{array}{l}\text { Five broad dimensions of } \\
\text { psychopathology based on } \\
\text { factor-analysis. }\end{array}$ & $\begin{array}{l}\text { - Aggressiveness-Revised, AGGR-r } \\
\text { • Psychoticism-Revised, PSYC-r } \\
\text { • Discontraint-Revised, DISC-r } \\
\text { • Negative Emotionality/ Neurot.-Revised, NEGE-r } \\
\text { • Introversion/Low Positive Emotionality-Revised, } \\
\text { INTR-r }\end{array}$ \\
\hline
\end{tabular}

${ }^{a}$ Not all MMPI scales are listed in the table.

bonly the Restructured Clinical scales are listed for the thought dysfunction area (following McCord, 2018, Figure $1.1)$.

The integration across multiple assessment languages is performed in Table 6 by establishing four columns to the right for psychiatric syndromes, personality traits, the R-PAS, and MMPI-2-RF. Each example of a symptom, trait, and test score is placed in its appropriate column, in the row corresponding to the personality function it describes.

For example, the psychiatric symptom cluster of Disinhibition is placed under psychiatric symptoms in the "self-control" row because it describes a lack of personal discipline, and the MMPI-2-RF score of Disconstraint-revised (DISC-r) falls under the MMPI-2-RF column in the same row. As a second example, the Big Five trait of Neuroticism-Stability and the R-PAS YTVC' score, which represents multiple implicit signs of distress, describe the functioning of the emotion system and are aligned in the emotions row. Many of the examples of symptoms, traits, 
Table 6

Functional Divisions of Personality and their Corresponding Psychiatric Symptom Areas, Personality Traits, and Selected Test Scores ${ }^{a}$

\begin{tabular}{|c|c|c|c|c|c|}
\hline Key functions & Subdivisions & HiTOP Clusters & Personality Traits & R-PAS & MMPI-2-RF \\
\hline \multirow{4}{*}{$\begin{array}{l}\bullet \text { Executive } \\
\text { Consciousness }\end{array}$} & conscious awareness & -- & absorption & -- & Aberrant Experiences, $\mathrm{RC}^{\mathrm{a}}$ \\
\hline & self-control & disinhibition & conscientious-carelessness & Human movement, $\mathrm{M}$ & Discontraint-Revised, DISC-r \\
\hline & coping and defense & -- & $\begin{array}{l}\text { repression-sensitization; level of } \\
\text { defense; coping skills }\end{array}$ & $\begin{array}{l}\text { MC in rel. to Potentially Proble- } \\
\text { matic Determinants MC-PPD }\end{array}$ & Uncommon Virtues, L-r \\
\hline & the self (blend) & -- & self-esteem; self-efficacy & Ego Impairment Index-3, EII-3 & Juvenile Conduct Problems, JCP ${ }^{\mathrm{b}}$ \\
\hline \multirow[t]{3}{*}{$\begin{array}{l}\text { - Action } \\
\text { Implementation }\end{array}$} & relationship styles & $\begin{array}{l}\text { antagonistic- } \\
\text { externalizing } \\
\text { anti-social behavior }\end{array}$ & $\begin{array}{l}\text { attachment, secure and insecure; } \\
\text { agreeableness-disagreeableness }\end{array}$ & $\begin{array}{l}\text { Prompts needed to elicit responses, } \\
\text { Pr; Cooperative movement COP }\end{array}$ & $\begin{array}{l}\text { Aggressiveness-Rev., AGGR-r } \\
\text { Aggression, AGG }\end{array}$ \\
\hline & acquired skills & & honesty/humility-dishonesty/arrogan. & -- & -- \\
\hline & $\begin{array}{l}\text { emotion-modulated } \\
\text { relationship styles } \\
\text { (blend) }\end{array}$ & detachment & extraversion-introversion & & $\begin{array}{l}\text { Behavior-Restricting Fears, BRF; } \\
\text { Interpersonal Passivity, IPP; Social } \\
\text { Avoidance, SAV; Introver./ Low } \\
\text { Pos. Emot., INTR-r }\end{array}$ \\
\hline \multirow[t]{4}{*}{$\begin{array}{l}\text { - Knowledge } \\
\text { Guidance }\end{array}$} & $\begin{array}{l}\text { knowledge (and } \\
\text { schemas) }\end{array}$ & -- & -- & $\begin{array}{l}\text { Human movement and weighted } \\
\text { color, MC; Human movement with } \\
\text { poor form, M-; Human, H }\end{array}$ & -- \\
\hline & intelligences & cognitive disabilities $^{\mathrm{a}}$ & $\begin{array}{l}\text { general intelligence, verbal- } \\
\text { comprehension, etc. }\end{array}$ & Complexity $^{\mathrm{c}}$ & -- \\
\hline & cognitive styles & thought disorder & $\begin{array}{l}\text { openness-closedness; internal-external } \\
\text { locus of control; need for cognition }\end{array}$ & $\begin{array}{l}\text { Weighted Sum of Six Cognitive } \\
\text { Codes, WSumCog; Synthesis, Sy; } \\
\text { Human, H-; Form quality } \\
\text { percentages, FQo\% etc.; Popular, P }\end{array}$ & $\begin{array}{l}\text { Ideas of Persecution, RC6 }{ }^{\mathrm{a}} \\
\text { Psychoticism-Revised, PSYC-r }\end{array}$ \\
\hline & $\begin{array}{l}\text { motivation-and- } \\
\text { emotion-associated } \\
\text { thought (blend) }\end{array}$ & & optimism-pessimism & $\begin{array}{l}\text { R, number of responses; MOR } \\
\text { Morbid content thematic code }\end{array}$ & $\begin{array}{l}\text { Suicidal/Death Ideation, SUI; } \\
\text { Helplessness/ Hopeless, HLP; } \\
\text { Cognitive Complaints, COG; } \\
\text { Aesthetic-Literary Interests, AES; } \\
\text { Mech.-Physical Interests, MEC }\end{array}$ \\
\hline \multirow[t]{2}{*}{$\begin{array}{l}\text { - Energy } \\
\text { Development }\end{array}$} & emotions & mania, distress, fear & $\begin{array}{l}\text { neuroticism-stability; arousal-calm } \\
\text { affect; pleasant-unpleasant affect }\end{array}$ & $\begin{array}{l}\text { WSumC and }(\mathrm{CF}+\mathrm{C}) / \text { SumC; } \\
\text { Diffuse shading, Y, YTVC' }\end{array}$ & $\begin{array}{l}\text { Negative Emotionality/ } \\
\text { Neuroticism-Rev. NEGE-r }\end{array}$ \\
\hline & motives & -- & -- & -- & -- \\
\hline $\begin{array}{l}\text { - [Supplement] } \\
\text { Biopsychological } \\
\text { Dysfunctions }\end{array}$ & $\begin{array}{l}\text { Mixed medical, } \\
\text { neuropsychological, } \\
\text { self-management } \\
\text { issues }\end{array}$ & $\begin{array}{l}\text { substance abuse and } \\
\text { addictive disorders } \\
\text { somatoform disorders } \\
\text { eating pathol. (some) }\end{array}$ & -- & -- & $\begin{array}{l}\text { Gastroint. Complaints, GIC } \\
\text { Head Pain Complaints, HPC } \\
\text { Neurological Complaints, NUC } \\
\text { Substance Abuse, SUB }\end{array}$ \\
\hline
\end{tabular}

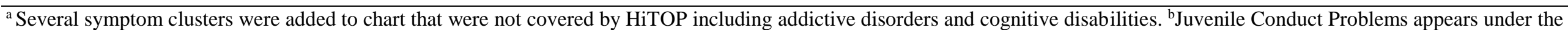
Self because of its historical nature; ${ }^{\mathrm{c} C o m p l e x i t y ~ i s ~ n o t ~ a b b r e v i a t e d . ~}$ 
and test scores examined earlier are placed side-by-side in a single, integrated depiction in Table 6 that allows for a convenient overview of what they say regarding a client.

A case example: beginnings. The PSF-A also can be used to integrate information from specific cases: for instance, from the case of "Cristina," a 22-year-old student at the Catholic University of Milan, who referred herself to the student counseling center (Fantini \& Smith, 2018), and underwent a therapeutic assessment (Finn, 2005).

The counseling staff viewed Cristina as a lively, outgoing, and self-disclosing client. The year before, however, Cristina had begun to experience discomfort after she had overheard her parents talk about her mother's extramarital affair; her parents announced plans to divorce shortly thereafter. Her mother left their home and Cristina remained with her father. Cristina felt anger at her mother initially over the affair but was sufficiently calm and reasonable to continue to perform well at school. As time went on, however, she felt more apathetic than she was accustomed to and her anger at her mother intensified.

Cristina's assessment questions included, "How can I get rid of the anger I feel toward my mother?" and, secondly concerned how she could reconnect with her emotions (Fantini \& Smith, 2018, p. 140).

Preliminary matters. Cristina took the MMPI-2-RF and R-PAS, and a partial selection of her test scores appears in Table 7, arranged to follow the PSF-A system. (Please refer to Fantini \& Smith, 2018, for the complete report). For brevity's sake, the table (and this narrative) focus on Cristina's functioning in the areas of (a) emotion, (b) self-control, and (d) relationship style. Note that scores on the MMPI are scaled to have a $M=50$ and $S=10$; those on the R-PAS are scaled to have a $M=100$ and $S=15$. R-PAS scores also can be complexity-adjusted (CAdj) to control for aspects of the test-taker's cognitive style (see Table 4, row 2). Cristina appeared involved when taking both tests (she provided 31 responses to the $R-P A S$ - an above-average number).

Emotions and emotion-influenced cognition. Consistent with the staff's observations that Cristina was lively, she obtained high R-PAS WSumC: a scaled score (SS) of 131, as well as other scores indicative of lively affect in healthy individuals (see Table 7, emotion row). Other R-PAS scores reflected her low implicit low distress, including low Y, m, and Morbid Content scores (Y, m, MOR, SSs $=85,84$, and 86). Cristina further reported below-average scores on the Helplessness/Hopelessness scale of the MMPI (HLP, $T=38)$. Yet her highest score on the MMPI 2-RF reflected her self-perceived anger and impatience with other people (ANP $=68$ ).

The self, coping and defense. On the Early Memories Procedure she was administered, Cristina reported that she had to cope for herself as a child because her parents were often far away. Those coping skills grew as she matured: On the R-PAS, she obtained a high Human Movement and Weighted Color index (MC, SS =138), which is characteristic of people with good adaptive resources and capacities (see Table 7, the self, coping and defense row). Cristina also exhibited minimal self-doubt on the MMPI (SFD =42). 
Table 7

Abridged Clinical Notes on "Cristina's" Personality Functions ${ }^{a b}$

\begin{tabular}{|c|c|c|c|c|c|c|}
\hline \multirow{2}{*}{$\begin{array}{l}\text { Key. } \\
\text { functions }\end{array}$} & \multirow[t]{2}{*}{ Subdivis. } & \multicolumn{2}{|r|}{ R-PAS } & \multicolumn{2}{|c|}{ MMPI-2-RF } & \multirow{2}{*}{$\begin{array}{l}\text { Other Tests, Interview Data and } \\
\text { Additional Observations }{ }^{\mathrm{d}}\end{array}$} \\
\hline & & Selected Scores ${ }^{\mathrm{c}}$ & Interpretation & Selected Scores & Interpretation & \\
\hline \multirow[t]{2}{*}{$\begin{array}{l}- \text { Executive } \\
\text { Consciousn. }\end{array}$} & self-control & $\mathrm{M} \mathrm{SS}=129$ & $\begin{array}{l}\text { An ability to exercise good } \\
\text { planning and judgment under } \\
\text { pressure and before engaging in } \\
\text { consequential acts }\end{array}$ & $\begin{array}{l}\text { Behavioral/ } \\
\text { Externalizing } \\
\text { Dysfunct., BXD = } 39\end{array}$ & $\begin{array}{l}\text { Self-evaluation of highly } \\
\text { self controlled }\end{array}$ & $\begin{array}{l}\text { Observation. High functioning at } \\
\text { college, even when under stress. }\end{array}$ \\
\hline & $\begin{array}{l}\text { the self, } \\
\text { coping and } \\
\text { defense }\end{array}$ & $\begin{array}{l}\text { MC Cadj = 122; } \\
\text { MC-PPD CAdj SS = } \\
\text { 148; Complx.- } \\
\text { Adjust. Coping: COP } \\
\text { CAdj SS= } 112\end{array}$ & $\begin{array}{l}\text { Many psychological strengths: } \\
\text { Possesses needed abilities, } \\
\text { socioemotional strengths, and } \\
\text { other helpful mental attributes in } \\
\text { relative abundance. Copes well } \\
\text { in the face of complexity and } \\
\text { adversity. }\end{array}$ & Self-Doubt, $\mathrm{SFD}=42$ & $\begin{array}{l}\text { Regards herself as high in } \\
\text { self-confidence }\end{array}$ & $\begin{array}{l}\text { Early Memories Procedure: } \\
\text { Cristina reported coping for herself } \\
\text { as child while her parents were far } \\
\text { away and unavailable; Interview. } \\
\text { Finds own anger (toward mother) } \\
\text { disturbing; regards anger as an } \\
\text { unproductive emotion (pp. 139-140). }\end{array}$ \\
\hline $\begin{array}{l}\text { - Action } \\
\text { Implement. }\end{array}$ & $\begin{array}{l}\text { relation. } \\
\text { styles }\end{array}$ & $\begin{array}{l}\text { H CAdj SS = 113; } \\
\text { SumH CAdj SS }= \\
116 ; \text { MAH CAdj SS } \\
=102\end{array}$ & $\begin{array}{l}\text { Attentive to people and readily } \\
\text { envisions healthy interactions } \\
\text { and relationships with them. }\end{array}$ & $\begin{array}{l}\text { AGG }=36 ; \\
\text { Aggression-Revised, } \\
\text { AGGR-r }=43\end{array}$ & $\begin{array}{l}\text { Low perceived aggression, } \\
\text { possibly with denial; low } \\
\text { perceived assertiveness }\end{array}$ & $\begin{array}{l}\text { Interview. Regarding attention, } \\
\text { she notes that she often listens to } \\
\text { others' problems, but doesn't } \\
\text { share her own concerns; }\end{array}$ \\
\hline $\begin{array}{l}\text { - Knowld. } \\
\text { Guidance }\end{array}$ & $\begin{array}{l}\text { knowledge } \\
\text { and } \\
\text { schemas }\end{array}$ & $\begin{array}{l}\mathrm{FQu} \% \mathrm{SS}=123 ; \mathrm{P} \\
\mathrm{SS}=126\end{array}$ & $\begin{array}{l}\text { Monitors key features in the } \\
\text { environment that may signal } \\
\text { challenges. Both unconventional- } \\
\text { subjective, and conventional- } \\
\text { stereotypical views. }\end{array}$ & -- & - & $\begin{array}{l}\text { Early Memories Procedure. } \\
\text { Cristina idealized her mother (and } \\
\text { father) and would not criticize } \\
\text { her/them. }\end{array}$ \\
\hline $\begin{array}{l}\text { - Energy } \\
\text { Develop. }\end{array}$ & emotions & $\begin{array}{l}\text { WSumC SS = 131; } \\
\text { Y SS = 85; } \mathrm{m} \text { SS = } \\
\text { 84; YTVC' CAdj SS } \\
=81 ; \text { MOR SS = 86; } \\
\text { PPD CAdj SS = 59; }\end{array}$ & $\begin{array}{l}\text { Liveliness; low distress; } \\
\text { potential exclusion of inner } \\
\text { feelings including exclusion of } \\
\text { often-normal sadness, distress, } \\
\text { and helplessness. }\end{array}$ & $\begin{array}{l}\text { Emotional/ Internal. } \\
\text { Dysfunction, EID } \\
=49 ; \text { Anger } \\
\text { Proneness, ANP }=68\end{array}$ & $\begin{array}{l}\text { Self-evaluated low } \\
\text { emotional distress; anger } \\
\text { and impatience with others. }\end{array}$ & $\begin{array}{l}\text { Interview: Cristina's assessment } \\
\text { questions are "How can I 'get rid' } \\
\text { of anger" and "Why am I } \\
\text { apathetic/removed from } \\
\text { emotions?" }\end{array}$ \\
\hline
\end{tabular}

${ }^{\mathrm{a}}$ For the complete report, please see Fantini and Smith (2018).

${ }^{\mathrm{b}}$ The abbreviated table here is intended to provide examples of how the system can organize information from a clinical assessment. Only a subset of personality areas most relevant to the case are included. Additional functional areas would be represented in added rows; additional test results would be fit in added columns for, for example, observations of content and code sequences of R-PAS responses, and other test results and interview materials. (These are omitted here for reasons of length).

"Note that "CAdj" refers to scale scores that have been adjusted for complexity, i.e., a function of number of determinants, contents, locations and other intricacies.

${ }^{\mathrm{d} I n}$ a full table, contents of this column would be represented in three or more distinct columns of equivalent status to those focused on here. 
On the other hand, Cristina did see stressful percepts on the Rorschach cards, after which she exhibited an instance of impaired Human Movement perception (M-, SS =113), reflecting potential misunderstandings of others when she is under stress; she also expressed possible aggressive content (though it was incomplete).

Relationship style. On the MMPI, Cristina regarded herself as well self-controlled, and reported relatively few problems with aggression, or other externalizing actions on the Behavioral/Externalizing Dysfunction scale (BXD, $T=39)$ and related scales (see Table 7). On the R-PAS Cristina exhibited signs she was both attentive to others (an above-average MC CAdj, $\mathrm{SS}=122$ ), as well as a high Cooperative Movement score (COP CAdj SS =112), indicating her generally positive view of relations with others.

Considerations. As noted earlier, Fantini and Smith (2018) provide a full-length description of this case that includes many further elements. Even this brief account, however, can convey Cristina's concern over her anger coupled with her well-functioning coping, constructive relationships, and generally low distress.

In the aftermath of her parents' divorce, Cristina was beset by two somewhat contradictory facets of her self-concept: one as a cooperative, calm person, and the other as angry at her mother. Given the recent emergence of the second self-view, coupled with her youth, she likely had lacked the time and experience to integrate the two. The assessment staff believed on the basis of further data from the interview and tests, that Cristina also failed to express her anger constructively, and that encouraged her to bury it.

A therapist might encourage Cristina to explore her belief that anger was "useless" and whether anger could be adaptive in some circumstances, particularly if expressed constructively. Regarding Cristina's concern about reconnecting with her emotions, the counseling staff suggested that her apathetic feelings were likely due to shock and grieving over her parents' divorce, from which she could expect to recover over time (Fantini \& Smith, 2018, p. 146).

To return to the system proposed here, a fully developed version of Table 7 could promote a relatively holistic snapshot of Cristina's functioning at the time of the assessment by organizing data about her life history, behavior, implicit mental processes, and self-evaluations.

\section{Discussion}

\section{The Advantages—and Challenges—of Good Organization, Redux}

In a successful personality assessment, the clinician attempts to understand an individual so as to answer one or more referral questions of concern (Society for Personality Assessment, 2006, pp. 355-356). Clinical professionals bring to bear their special training in the area, including their knowledge of clinical interviewing, the interpretation of mental test scores, 
psychometrics and personality psychology more generally (Society for Personality Assessment, 2006).

Professionals must speak multiple technical languages concerning the individual's social context, including the vocabularies of diverse identities, family dynamics, school and work organizations, and socioeconomic status. They also must speak the languages of personality functioning, including those of psychiatric symptoms, mental traits, and specific tests. These technical languages are diverse in nature, and professionals in the area draw on integrative approaches to reduce the confusion that can result from switching terminology and concepts from one technical perspective to another (Beutler, 1995, p.52).

\section{The Personality System Framework applied to Assessment (PSF-A)}

The Personality Systems Framework applied to Assessment (PSF-A) can be used to organize the information about a person communicated by such technical languages. The contextual organization draws on the main areas surrounding personality to provide a system to record the client's underlying medical health, physical settings, situations, and group memberships (Table 1). The PSF-A functional organization provides a system to record data relevant to a person's inner mental life and its expressions, and its functionality in the broad areas of energy development, knowledge guidance, action implementation, and executive management.

The functional outline uses personality functions to group psychiatric symptoms, traits, and test scores by the area each describes. For example, a person's self-control is potentially characterized by a given level of clinical disinhibition, the trait of conscientiousness, an R-PAS score on human movement (M), and by an MMPI-2-RF Disconstraint score (DISC-R). These indices are positioned together in the self-control row of Table 6. Likewise, a person's relationship style can be characterized by psychiatric symptoms related to antagonism, the trait of disagreeableness, by an R-PAS Cooperative Movement (COP) score, and an MMPI Aggressiveness score (AGGR-r); these are positioned in the relationship styles row of Table 6.

\section{Practical Advantages of PSF-A}

The PSF-A contextual outline promotes a balanced view of the client. The PSF-A contextual outline records the person's contexts, from the client's health to their setting, situations, and ethnic, religious, and other identifications and group memberships. The outline promotes a balanced view of a client by representing a comprehensive catalog of the person's surrounding context, from the medical to the societal.

By comparison, professionals who avoid such systems may overlook one or more relevant areas of their client's concern: A therapist who is comfortable discussing gender identity but less so appraising religious belief may inadvertently overlook the intersectionality that arises from conflicts between gender identity and religion (e.g., Grieger, 2008). The PSF-A's 
complementary organizational systems for context and function make it more likely to uncover key information that can help address a given assessment question.

The PSF-A functional outline organizes diverse information about the client's inner functioning. The second, functional, outline of the PSF-A organizes and aligns the technical languages of psychiatric symptoms, personality traits, and test scores in a single chart, by aligning them according to the areas of personality they characterize. By grouping similar characterizations of personality together, clinicians, first, can quickly evaluate which findings are consistent and which are contradictory; second, can account for any such discrepancies, such as what it might mean for an individual to perceive herself as warm and friendly when others view her as domineering and cold (see, for example, the case of Madeline G. in Wiggins, 2003); and third, can draw conclusions as to which areas of a client's personality function are performing well or are impaired.

\section{The PSF-A may promote assessments that are more comprehensive in clinical}

practice. Beyond supporting professionals' assessment of their clients' key contextual and functional qualities, the framework may identify areas of personality that are under-assessed field-wide. For example, Table 6 indicates that relatively few scales from the MMPI-RF or RPAS (or Big Five, or intelligence scales) assess motivations such as the needs for achievement, power, or affiliation. Yet these can be readily measured through the use of picture-story techniques (Schultheiss \& Schultheiss, 2014). Nor are measures of internal-external locus of control included. Yet scores reflective of motives could inform assessment questions such as: "Is my client more motivated by a need to affiliate than by a need to achieve?" and "Does my client believe she lacks much personal control over what is going on around her?"

The PSF-A reduces cognitive load for the clinician, freeing up time for conceptualizing answers to referral questions. Organizing information as occurs when using a good classification system frees up resources in long-term working memory that are important to using one's expertise and intelligence (Ericsson \& Kintsch, 1995; Renkl, Hilbert, \& Schworm, 2009). The contextual and functional organizations here reduce the cognitive load on the assessment professional, allowing for the better application of their people-centered intelligences and expertise to reason about their clients' situations (Ericsson \& Kintsch, 1995; Mayer, 2014).

\section{Limitations and their Mitigation}

Comprehensive outlines can be burdensome. Although relatively comprehensive datagathering may be desirable for some research purposes, in everyday practice a clinician writing a report may not need or wish to include all the contexts or all personality functions covered in the PSF-A. Time and other practical constraints place limits on the amount of information a clinician can gather in relation to their client. It sometimes may be most effective to record only the more remarkable aspects of the data in a case evaluation and then to skip coverage of the less 
remarkable aspects, so as to focus on a psychological area or areas especially relevant to a given assessment question.

\section{Inconclusive assignments of symptoms, traits, and test scores to the functional areas.} Another issue is that despite the relatively clear distinction among the functional areas of the personality systems framework, the areas do overlap — and assessment information can be interpreted in different ways. For these reasons, the placement of specific psychiatric symptoms, traits, and test scores is not always as clear as would be desirable. For example, the R-PAS score of Achromatic Color ( $C^{\prime}$ ) potentially indicates dampened emotional reactivity or openness to a range of emotional experiences. Dampened emotional reactions describe the emotions area, whereas openness to emotionality is a cognitive style. A C' score also could be regarded as reflecting a lack of defensiveness, and could also be placed in the Defense and Coping area.

One way to mitigate these ambiguities would be to establish default placements of test scores and other data in the outlines, which could be overridden when interpretations called for it. Another approach would be to enter a score in multiple areas (i.e., rows), where it was relevant. That said, preliminary studies indicate that the PSF's division of functions, although imperfect, generally leads to better agreement in its sorting than do competing systems (Mayer, 2003).

\section{Where the organization leaves off and expertise and mental ability takes over. A} built-in limitation of the personality systems framework as applied to assessment is that its application stops before specific theorizing about a case begins. The framework is by design not an explanation of personality, but rather a tool for sorting and integrating information: The PSF's purpose is to employ the bare minimum of sound, consensual, field-wide assumptions (this promotes its pan-theoretical acceptability). For this reason, the approach includes no explanatory theories, allowing the professional to draw on relevant theory and their own reasoning to elucidate the case. Such reasoning might draw, for example, on the neo-Sullivanian interpersonal-situation outline presented by Blais and Hopwood (2017). Or, as a second example, the theorizing might draw on the works of Kübler-Ross, as the clinicians who worked with Cristina did, when they advised her that she might be moving through stages of grief over her parents' divorce, and that she would be likely reconnect with her feelings once that working through was complete.

\section{Concluding Thoughts}

One of an assessment professional's chief tasks is to organize the multifaceted data about a person collected during an assessment. The contextual and functional organizations developed here are designed to facilitate the recording and organizing of such data. When professionals make meaning of what they have learned, however, they need to draw on their professional training, life experience, and their capacity to reason about a person and the possible scope of the person's future behavior, to best apply their powers of understanding and prediction (Mayer, 
2014, pp. 203-206). Using a good system for organizing knowledge during the assessment process reduces the clinicians' cognitive load, freeing the professional to focus on optimally conceptualizing their clients' characteristics while addressing the key assessment questions at hand.

\section{References}

American Psychiatric Association. (2013). Diagnostic and statistical manual of mental disorders: DSM-5 ${ }^{\mathrm{TM}}$ (5th ed.). Arlington, VA US: American Psychiatric Publishing, Inc.

Anchin, J. C. (2008). Pursuing a unifying paradigm for psychotherapy: Tasks, dialectical considerations, and biopsychosocial systems metatheory. Journal of Psychotherapy Integration, 18(3), 310-349. doi.org/10.1037/a0013557

Ashton, M. C., \& Lee, K. (2010). Trait and source factors in HEXACO-PI-R self- and observer reports. European Journal of Personality, 24(3), 278-289. 10.1002/per.759

Averill, J. R. (1992). The structural bases of emotional behavior: A metatheoretical analysis. In M. S. Clark (Ed.), Emotion. (pp. 1-24). Thousand Oaks, CA US: Sage Publications, Inc.

Barlow, B. A., \& Mayer, J. D. (2014). Mapping the mind Poster presented at the American Psychological Association Annual Convention. August, 2014.

Barlow, B. A., \& Mayer, J. D. (2015). Mapping the mind and its traits. Poster presented at the Association of Research in Personality Bi-Annual Conference.

Ben-Porath, Y. S., \& Tellegen, A. (2011). MMPI-2-RF (minnesota multiphasic personality inventory-2 restructured form): Manual for administration, scoring and interpretation. . Minneapolis: University of Minnesota Press.

Ben-Porath, Y. S. (2017). An update to williams and lally's (2016) analysis of MMPI-2-RF acceptance. Professional Psychology: Research and Practice, 48(4), 275-278. doi.org/10.1037/pro0000115

Ben-Porath, Y. S., \& Tellegen, A. (2012). MMPI-2-rf interpretive report: Clinical settings. (). Minneapolis, MN: Pearson Education.

Beutler, L. E. (1995). Integrating and communicating findings. In L. E. Beutler, \& M. R. Berren (Eds.), Integrative assessment of adult personality (pp. 25-64). New York: Guilford.

Blais, M. A., \& Hopwood, C. J. (2017). Model-based approaches for teaching and practicing personality assessment. Journal of Personality Assessment, 99(2), 136-145. doi.org/10.1080/00223891.2016.1195393

Blais, M. A., \& Smith, S. R. (2014). Improving the integrative process in psychological assessment: Data organization and report writing. In R. P. Archer, S. R. Smith, R. P. Archer \& S. R. Smith (Eds.), (pp. 433-469). New York, NY, US: Routledge/Taylor \& Francis Group.

Brabender, V. M., \& Mihura, J. L. (2016). The construction of gender and sex, and their implications for psychological assessment. In V. M. Brabender, J. L. Mihura (Eds.), 
Handbook of gender and sexuality in psychological assessment (pp. 3-43). New York, NY, US: Routledge/Taylor \& Francis Group.

Drill, R., Nakash, O., DeFife, J. A., \& Westen, D. (2015). Assessment of clinical information: Comparison of the validity of a structured clinical interview (the SCID) and the clinical diagnostic interview. Journal of Nervous and Mental Disease, 203(6), 459-462.

Ericsson, K. A., \& Kintsch, W. (1995). Long-term working memory. Psychological Review, 102(2), 211-245. 10.1037/0033-295X.102.2.211

Erikson, E. H. (1950). Childhood and society. New York: W. W. Norton.

Fantini, F., \& Smith, J. D. (2018). Using R-PAS in the therapeutic assessment of a university student with emotional disconnection. In J. L. Mihura \& G. J. Meyer (Eds.), Using the Rorschach Performance Assessment System (R-PAS) (pp. 138-157). New York, NY, US: Guilford Press.

Fernndez-lvarez, H., Consoli, A. J., \& Gmez, B. (2016). Integration in psychotherapy: Reasons and challenges. American Psychologist, 71(8), 820-830. doi.org/10.1037/amp0000100

Finn, S. E. (2005). How psychological assessment taught me compassion and firmness. Journal of Personality Assessment, 84(1), 29-32. doi.org/10.1207/s15327752jpa8401_07

Finn, S. E., \& Martin, H. (2013). Therapeutic assessment: Using psychological testing as brief therapy. In K. F. Geisinger, B. A. Bracken, J. F. Carlson, J. C. Hansen, N. R. Kuncel, S. P. Reise, S. P. \&. M. C. Rodriguez (Eds.), APA Handbook of Testing and Assessment in Psychology (pp. 453-465). Washington, DC, US: American Psychological Association.10.1037/14048-026

Finn, S. E., \& Tonsager, M. E. (1997). Information-gathering and therapeutic models of assessment: Complementary paradigms. Psychological Assessment, 9(4), 374-385. 10.1037/1040-3590.9.4.374

Funder, D. C. (1998). Why does personality psychology exist? Psychological Inquiry, 9(2), 150152. doi.org/10.1207/s15327965pli0902_13

Goldberg, L. R. (1993). The structure of phenotypic personality traits. American Psychologist, 48(1), 26-34. 10.1037/0003-066X.48.1.26

Green, C. D. (2015). Why psychology isn't unified, and probably never will be. Review of General Psychology, 19(3), 207-214. doi.org/10.1037/gpr0000051

Grieger, I. (2008). A cultural assessment framework and interview protocol. In L. A. Suzuki \& J. G. Ponterotto (Eds.), Handbook of Multicultural Assessment, $3^{\text {rd }}$ ed. (pp. 132-161). San Francisco, CA, US: Jossey-Bass.

Harwood, M. T., Beutler, L. E., \& Groth-Marnat, G. (Eds.). (2011). Integrative assessment of adult personality (Third edition ed.). New York: The Guilford Press.

Helson, R., Mitchell, V., \& Moane, G. (1984). Personality and patterns of adherence and nonadherence to the social clock. Journal of Personality and Social Psychology, 46(5), 1079-1096. doi.org/10.1037/0022-3514.46.5.1079 
Kici, G., \& Westhoff, K. (2004). Evaluation of requirements for the assessment and construction of interview guides in psychological assessment. European Journal of Psychological Assessment, 20(2), 83-98. 10.1027/1015-5759.20.2.83

Kotov, R., Krueger, R. F., Watson, D., Achenbach, T. M., Althoff, R. R., Bagby, R. M., . . Zimmerman, M. (2017). The hierarchical taxonomy of psychopathology (HiTOP): A dimensional alternative to traditional nosologies. Journal of Abnormal Psychology, 126(4), 454-477. doi.org/10.1037/abn0000258.supp (Supplemental)

Kozhevnikov, M., Evans, C., \& Kosslyn, S. M. (2014). Cognitive style as environmentally sensitive individual differences in cognition: A modern synthesis and applications in education, business, and management. Psychological Science in the Public Interest, 15(1), 3-33. 10.1177/1529100614525555

Laska, K. M., Gurman, A. S., \& Wampold, B. E. (2014). Expanding the lens of evidence-based practice in psychotherapy: A common factors perspective. Psychotherapy, 51(4), 467-481. doi.org/10.1037/a0034332

Lopez, S. R. (2002). Teaching culturally informed psychological assessment: Conceptual issues and demonstrations. Journal of Personality Assessment, 79(2), 226-234. 10.1207/S15327752JPA7902_06

Maddi, S. R. (2006). Taking the theorizing in personality theories seriously: Comment. American Psychologist, 61(4), 330-331. 10.1037/0003-066X.61.4.330

Magnavita, J. J. (2008). Toward unification of clinical science: The next wave in the evolution of psychotherapy? Journal of Psychotherapy Integration, 18(3), 264-291. 10.1037/a0013490

Mayer, J. D. (1993). A system-topics framework for the study of personality. Imagination, Cognition and Personality, 13(2), 99-123. doi.org/10.2190/0B5Y-6M4L-7939-FJD8

Mayer, J. D. (1995a). A framework for the classification of personality components. Journal of Personality, 63(4), 819-878. doi.org/10.1111/1467-6494.ep9512221953

Mayer, J. D. (1995b). The system-topics framework and the structural arrangement of systems within and around personality. Journal of Personality, 63(3), 459-493. doi.org/10.1111/j.1467-6494.1995.tb00503.x

Mayer, J. D. (1998a). A systems framework for the field of personality. Psychological Inquiry, 9(2), 118-144. doi.org/10.1207/s15327965pli0902_10

Mayer, J. D. (1998b). The systems framework: Reception, improvement, and implementation. Psychological Inquiry, 9(2), 169-179. doi.org/10.1207/s15327965pli0902_19

Mayer, J. D. (2001). Primary divisions of personality and their scientific contributions: From the trilogy-of-mind to the systems set. Journal for the Theory of Social Behaviour, 31(4), 449.

Mayer, J. D. (2003). Structural divisions of personality and the classification of traits. Review of General Psychology, 7(4), 381-401. doi.org/10.1037/1089-2680.7.4.381

Mayer, J. D. (2014). Personal intelligence: The power of personality and how it shapes our lives. New York: Scientific American / Farrar Strauss \& Giroux. 
Mayer, J. D. (2015). The personality systems framework: Current theory and development. Journal of Research in Personality, doi.org/10.1016/j.jrp.2015.01.001

Mayer, J. D. (2018). The functional areas of personality. Retrieved from https://mypages.unh.edu/jdmayer/personality-systems-framework

Mayer, J. D., \& Allen, J. L. (2013). A personality framework for the unification of psychology. Review of General Psychology, 17(2), 196-202. doi.org/10.1037/a0032934

Mayer, J. D., Faber, M. A., \& Xu, X. (2007). Seventy-five years of motivation measures (19302005): A descriptive analysis. Motivation and Emotion, 31(2), 83-103. 10.1007/s11031-0079060-2

Mayer, J. D., \& Lang, J. L. (2011). A three-dimensional view of personality. Psychological Inquiry, 22(1), 36-39. doi.org/10.1080/1047840X.2011.544635

McCord, D. M. (2018). Overview of the MMPI-2-RF: History, development, and psychometric considerations. (pp. 7-17). Washington, DC, US: American Psychological Association.doi.org/10.1037/0000074-002

McGrew, K. S. (2009). CHC theory and the human cognitive abilities project: Standing on the shoulders of the giants of psychometric intelligence research. Intelligence, 37(1), 1-10. 10.1016/j.intell.2008.08.004

Meyer, G. J., Viglione, D. J., Mihura, J. L., Erard, R. E., \& Erdberg, P. (2011). Rorschach performance assessment system. administration, coding, interpretation, and technical manual. Toledo, OH: Rorschach Performance Assessment System, LLC.

Mischel, W., \& Shoda, Y. (1995). A cognitive-affective system theory of personality: Reconceptualizing situations, dispositions, dynamics, and invariance in personality structure. Psychological Review, 102(2), 246-268. doi.org/10.1037/0033-295X.102.2.246

Renkl, A., Hilbert, T., \& Schworm, S. (2009). Example-based learning in heuristic domains: A cognitive load theory account. Educational Psychology Review, 21(1), 67-78.

10.1007/s10648-008-9093-4

Schultheiss, O. C., \& Schultheiss, M. (2014). Implicit motive profile analysis: An if-then contingency approach to the picture-story exercise. Social and Personality Psychology Compass, 8(1), 1-16. 10.1111/spc3.12082

Sheldon, K. M. (2011). Consilience within the biopsychosocial system. Psychological Inquiry, 22(1), 52-65. doi.org/10.1080/1047840X.2011.551105

Sheldon, K. M., Cheng, C., \& Hilpert, J. (2011). Understanding well-being and optimal functioning: Applying the multilevel personality in context (MPIC) model. Psychological Inquiry, 22, 1-16.

Sheldon, K. M., \& Kasser, T. (1995). Coherence and congruence: Two aspects of personality integration. Journal of Personality and Social Psychology, 68(3), 531-543.

Singer, J. A. (1998). Applying a systems framework to self-defining memories. Psychological Inquiry, 9(2), 161-164. 
Singer, J. L. (1984). The private personality. Personality and Social Psychology Bulletin, 10(1), 7-30. 10.1177/0146167284101002

Society for Personality Assessment. (2006). Standards for education and training in psychological assessment. position of the society for personality assessment. Journal of Personality Assessment, 87(3), 355-357. doi.org/10.1207/s15327752jpa8703_17

Sugarman, A. (1991). Where's the beef? putting personality back into personality assessment. Journal of Personality Assessment, 56(1), 130-144. 10.1207/s15327752jpa5601_12

Wiggins, J. S. (2003). Paradigms of personality assessment: An interpersonal odyssey. Journal of Personality Assessment, 80(1), 11-18. doi.org/10.1207/S15327752JPA8001_08 